\title{
Literasi Digital dalam Pembentukan Karakter Siswa di MTs Uswatun Hasanah Mirza Kota Binjai
}

\author{
M. Faisal Husna*1, Tri Reni Novita² \\ ${ }^{1}$ Program Studi Pendidikan Kewarganegaraan, FKIP, UMN Al Washliyah, Indonesia \\ 2Program Studi Ilmu Hukum, FH, UMN Al Washliyah, Indonesia \\ *e-mail: $\underline{\text { faisal.husna@umnaw.ac.id }}{ }^{1}, \underline{\text { trireninovita@gmail.com }}^{2}$
}

\begin{abstract}
Abstrak
Dampak COVID-19 bagi Pendidikan adalah pembelajaran melalui daring yang dilakukan guru dengan siswa. Banyak keluhan yang disampaikan orang tua siswa kepada pihak sekolah terkait pembelajaran daring dan salah satunya di MTs Uswatun Hasanah Mirza Kota Binjai. Keluhan tersebut berupa penggunaan gadget yang sulit diawasi, menurunnya minat belajar hingga perilaku anak yang dinilai kurang menghargai orang lain. Kemudahan akses dalam penggunaan gadget membuat anak keasyikan sehingga mengabaikan aktifitas lainnya seperti mengerjakan tugas sekolah, mengerjakan ibadah, membantu orang tua, bahkan sampai kepada ketidak pedulian anak ketika dipanggil orang tuanya sehingga dikhawatirkan berdampak pada karakter anak di masa yang akan datang. Mengingat siswa/i MTs Uswatun Hasanah Mirza merupakan sekolah berbasis pendidikan agama yang memiliki visi terwujudnya warga madrasah yang Disiplin, Cerdas, Terampil dan Berakhlaq Mulia serta memiliki Daya Saing di Tingkat Nasional maka penting untuk melakukan kegiatan pengabdian kepada masyarakat dengan tema literasi digital dalam pembentukan karakter. Melalui metode ceramah dengan teknik presentasi materi dan diskusi, kegiatan ini memberikan semangat dan antusias siswa di mana 75\% memahami dengan baik materi yang disampaikan dan hasilnya siswa bersedia menjadi duta kampanye gerakan literasi digital dalam pembentukan karakter yang berlandaskan Pancasila dan Bhinneka Tunggal Ika di sekolahnya.
\end{abstract}

Kata kunci: COVID-19, Literasi Digital, Pembentukan Karakter

\begin{abstract}
The impact of COVID-19 for education is online learning that is carried out by teachers and students. Many parents complained to the school regarding online learning and one of them was at MTs Uswatun Hasanah Mirza, Binjai City. The complaints are in the form of using gadgets that are difficult to supervise, decreasing interest in learning to the behavior of children who are considered to have little respect for others. The ease of access in using gadgets makes children so preoccupied that they ignore other activities such as doing schoolwork, doing worship, helping parents, even to the point of not caring about children when called by their parents so that it is feared that it will have an impact on children's character in the future. Considering that MTs Uswatun Hasanah Mirza students are a religious education-based school that has a vision of realizing Madrasah citizens who are Disciplined, Intelligent, Skilled and Has Noble Morals and have Competitiveness at the National Level, it is important to carry out community service activities with the theme of digital literacy in character building. . Through the lecture method with material presentation and discussion techniques, this activity provides enthusiasm and enthusiasm for students where $75 \%$ understand well the material presented and as a result students are willing to become campaign ambassadors for the digital literacy movement in character building based on Pancasila and Bhinneka Tunggal Ika in their schools.
\end{abstract}

Keywords: Character Building, COVID-19, Digital Literacy

\section{PENDAHULUAN}

\subsection{Latar Belakang Masalah}

Perkembangan teknologi digital saat ini begitu pesat yang ditandai dengan munculnya berbagai aplikasi maupun media teknologi dalam memenuhi kebutuhan hidup manusia. Sebut saja seperti belajar online, belanja online, cinema online, go-food, game online dan lainnya. Pendek kata, di abad 21 ini semua serba canggih dan apa yang menjadi kebutuhan manusia 
cukup dengan menggunakan jari. Kondisi COVID-19 yang melanda dunia termasuk Indonesia ditandai dengan pembatasan kegiatan manusia "memaksa" aktivitas dilakukan dari rumah, baik itu bekerja dari rumah, belajar dari rumah dan sebagainya sehingga penggunaan teknologi digital yang bervariasi dan inovatif semakin dibutuhkan. Namun harus diingat bahwa penggunaan berbagai teknologi digital tersebut membawa dampak positif dan negatif. Dampak positif tersebut misalnya seperti menghubungkan orang di seluruh dunia, penyebaran informasi yang cepat, munculnya media sosial, sarana berbagi file, memajukan dunia pendidikan, sedangkan dampak negatif seperti menurunkan semangat juang bagi sebagian orang karena semuanya serba mudah maka banyak murid yang hanya copy paste dalam mengerjakan tugastugas yang diberikan. Dalam bidang bisnis, kemajuan teknologi komunikasi juga memicu maraknya cybercrime, kejahatan virtual seperti hacking dan carding telah merugikan banyak orang. Begitu juga dalam kehidupan sosial seperti cyberbullying, penyebaran hoaks, ujaran kebencian dan konten pornografi dinilai cukup meresahkan. Dampak yang ditimbulkan pun bukan perkara sepele karena akan merusak generasi bangsa dan memecah belah persatuan. Oleh karena itu perlu pemahaman mengenai literasi digital dalam pembentukan karakter agar setiap orang/siswa aman dalam menggunakan teknologi tersebut.

Madrasah Tsanawiyah (MTs) Uswatun Hasanah Mirza Binjai sebagai lokasi kegiatan pengabdian masyarakat terletak di jalan T. Amir Hamzah Km.27 Gang Bakti kelurahan Jati Utomo kecamatan Binjai Utara. Madrasah yang sudah terakreditasi B ini dapat dikatakan strategis karena letaknya berada tidak jauh dari jalan besar lintas Medan-Banda Aceh di kota Binjai. Berdasarkan informasi dari kepala sekolah/madrasah bahwa selama COVID-19 terjadi sekitar hampir dua tahun maka kegiatan pembelajaran dilakukan secara daring. Selama proses itu pula banyak keluhan yang disampaikan oleh para orang tua kepada pihak sekolah terkait pembelajaran daring dimaksud. Keluhan tersebut seperti:

a. Penggunaan hp/gadget/teknologi komunikasi lainnya yang digunakan siswa secara berlebihan tanpa pendampingan seperti dalam bermedia sosial tanpa batas.

b. Menurunnya minat belajar siswa ditandai dengan kecenderungan siswa bermain game online.

c. Perilaku siswa yang dinilai kurang menghargai dan menghormati orang lain terlebih orang tua dan keluarga.

Penggunaan teknologi digital seperti gadget dalam pembelajaran daring dilakukan pada saat jam pelajaran berlangsung. Namun setelah selesai jam pelajaran maka siswa memanfaatkan gadget tersebut untuk bersenang-senang mencari hiburan seperti bermain game online, menonton film, tiktokan, update status, bermedia sosial, melihat konten-konten pornografi dan lain sebagainya. Kegiatan tersebut hampir dilakukan setiap hari dan tidak mengenal waktu sehingga para orang tua menyebutkan tidak mungkin untuk mengawasinya, mengingat mereka juga memiliki aktifitas lainnya. Dampak dari kegiatan tersebut membuat siswa lupa waktu, lupa belajar sehingga mengakibatkan penurunan minat belajar, kurangnya konsentrasi siswa hingga perilaku yang kurang dan bahkan tidak menghargai atau menghormati orang tua atau orang lain. Penurunan minat belajar ditandai dengan hasil belajar siswa kelas IX yang rendah dan lambannya setoran hafalan Al Qur'an yang menjadi tugas dan kebiasaan siswa/i di sekolah/madrasah. Menurut para orang tua semenjak pembelajaran daring ada perubahan sikap perilaku anak di rumah. Biasanya anak bangun pagi untuk sholat subuh namun karena anak terlalu banyak bermain game online bahkan hingga larut malam sehingga tidak bisa bangun pagi lagi. Selain dari itu perilaku anak yang tidak bisa diatur, cenderung melawan juga menjadi kekhawatiran dan kegalauan orang tua, seperti biasanya selepas pembelajaran daring anak membantu orang tua yang bekerja di ladang namun karena sering bermedia sosial, bermain game online maka ketika disuruh untuk membantu mereka malas-malasan.

Oleh karenanya mitra berharap melalui kegiatan pengabdian kepada masyarakat dengan tema literasi digital dalam pembentukan karakter dapat lebih memperkuat dan mempertajam pemahaman siswa serta mengubah mindset dalam penggunaan teknologi digital sehingga karakter yang diharapkan dan sejalan dengan visi misi madrasah dapat terwujud.

\subsection{Kajian Literatur}




\subsubsection{Literasi Digital}

Literasi digital adalah pengetahuan dan kemampuan untuk menggunakan teknologi digital, alat-alat komunikasi, atau jaringan dalam proses menemukan, mengevaluasi, menggunakan, dan membuat informasi, serta memanfaatkannya secara sehat, bijak, cerdas, cermat, tepat, dan patuh hukum sesuai dengan kegunaannya dalam rangka membina komunikasi dan interaksi dalam kehidupan sehari-hari (Wikipedia, 2021). Gilster (2012) mengemukakan bahwa literasi digital adalah kemampuan menggunakan teknologi dan informasi dari piranti digital secara efektif dan efisien dalam berbagai konteks seperti akademik, karir dan kehidupan sehari-hari. Sementara Sekretariat TIM GLN Kemdikbud mendefinisikan literasi digital merupakan kemampuan menggunakan teknologi informasi dan komunikasi (TIK) untuk mengkomunikasikan konten/informasi dengan kecakapan kognitif dan teknikal (Sekretariat TIM GLN Kemdikbud, 2017).

\subsubsection{Prinsip Dasar Literasi Digital}

Rullie Nasrullah, dkk (2017) mengemukakan bahwa literasi digital memiliki empat prinsip dasar pengembangan, yaitu: 1) Pemahaman, artinya masyarakat memiliki kemampuan untuk memahami informasi yang diberikan media, baik secara implisit ataupun eksplisit. 2) Saling ketergantungan, artinya antara media satu dengan lainnya saling bergantung dan berhubungan. Media yang ada harus saling berdampingan serta melengkapi antara satu sama lain. 3) Faktor sosial, artinya media saling berbagi pesan atau informasi kepada masyarakat. 4) Kurasi, artinya masyarakat memiliki kemampuan untuk mengakses, memahami serta menyimpan informasi untuk dibaca di lain hari. Kurasi juga termasuk kemampuan bekerjasama untuk mencari, mengumpulkan serta mengorganisasi informasi yang dinilai berguna.

\subsubsection{Manfaat Literasi Digital}

Manfaat literasi digital yaitu:

a. Kegiatan mencari dan memahami informasi dapat menambah wawasan individu.

b. Meningkatkan kemampuan individu untuk lebih kritis dalam berpikir serta memahami informasi.

c. Menambah penguasaan 'kosa kata' individu, dari berbagai informasi yang dibaca.

d. Meningkatkan kemampuan verbal individu.

e. Literasi digital dapat meningkatkan daya fokus serta konsentrasi individu.

\subsubsection{Tantangan Literasi Digital}

Literasi digital memiliki dua tantangan yang harus dihadapi dan tantangan ini bisa diatasi dengan menerapkan literasi digital dalam setiap penggunaan teknologi informasi dan komunikasi. Tantangan tersebut berupa:

a. Arus informasi yang banyak; tantangan ini paling kuat artinya masyarakat terlalu banyak menerima informasi disaat yang bersamaan. Dalam hal inilah literasi digital berperan, yakni untuk mencari, menemukan, memilah serta memahami informasi yang benar dan tepat.

b. Konten negatif; seperti konten pornografi, hoaks, isu SARA dan lainnya. Kemampuan individu dalam mengakses internet, khususnya teknologi informasi dan komunikasi, harus dibarengi dengan literasi digital sehingga individu bisa mengetahui mana konten yang positif dan bermanfaat serta mana konten negatif (https://www.dosenpendidikan.co.id/literasi-adalah/, 2021).

\subsubsection{Pembentukan Karakter}

Kemendikbud mendefinisikan karakter sebagai bentuk cara berfikir serta berperilaku seseorang yang nantinya akan menjadi ciri khasnya. Sementara Hanna Djumhana Bastaman mengatakan karakter merupakan bentuk dari aktualisasi diri serta internalisasi nilai serta moral yang berasal dari luar menjadi satu ke dalam bagian kepribadiannya (Savitra, 2017). Lickona dalam Saptono (2011:23) berpendapat bahwa Pendidikan karakter adalah upaya yang dilakukan dengan sengaja untuk mengembangkan karakter yang baik (good character) 
berlandaskan kebajikan-kebajikan inti (core virtues) yang secara objektif baik bagi individu maupun masyarakat. Kemudian Menurut Soemarno Soedarsono, pendidikan karakter sebagai sebuah nilai yang sudah tertanam di dalam diri sendiri. Nilai tersebut didapat melalui pendidikan, pengorbanan, percobaan, pengalaman dan pengaruh lingkungan yang mana kemudian dipadukan dengan nilai-nilai yang terdapat pada seseorang. Nilai-nilai tersebut menjadi nilai intrinsik yang mendasari sikap, perilaku, dan pemikiran seseorang. Menurut T. Ramli, pendidikan karakter adalah pendidikan yang mengedepankan esensi dan makna terhadap moral dan akhlak sehingga hal tersebut akan mampu membentuk pribadi peserta didik yang baik (Administrator, 2019). Pembentukan karakter lebih kurang hampir sama dengan pendidikan karakter karena pembentukan karakter dapat dilakukan melalui pendidikan yang terencana, artinya melalui pendidikan seseorang dibentuk menjadi pribadi bermoral yang dapat menghayati kebebasan dan tanggung jawabnya dalam hubungannya dengan orang lain di dalam komunitas pendidikan.

Siswa sebagai generasi penerus bangsa dan agen of change memiliki peran penting dalam estafet kepemimpinan di masa yang akan datang. Melalui proses pendidikan formal siswa mendapat pembinaan karakter sebagai bekal dalam melanjutkan roda pembangunan untuk tercapainya tujuan Indonesia sejahtera. Undang-Undang Sistem Pendidikan Nasional Nomor 20 Tahun 2003 menyatakan bahwa tujuan pendidikan nasional adalah mengembangkan potensi peserta didik untuk memiliki kecerdasan, kepribadian dan akhlak mulia. Tujuan Pendidikan dimaksud tidak hanya membentuk insan Indonesia yang cerdas, namun juga berkepribadian atau lebih berkarakter sehingga melahirkan generasi yang berkarakter sesuai nilai-nilai luhur bangsa dan agama (Ahlah \& Melianah, 2020).

\section{METODE}

Permasalahan mitra yang sudah diungkapkan di atas diselesaikan menggunakan metode ceramah dengan teknik presentasi materi dan diskusi. Presentasi materi dengan memberikan pemahaman terkait konsep literasi digital, pengenalan beberapa aplikasi teknologi serta media sosial dan cara bijak menggunakan teknologi komunikasi. Selain itu dipaparkan juga mengenai konsep pembentukan karakter. Setelah presentasi materi dilanjutkan dengan diskusi antara pemateri dengan siswa untuk mengetahui respon dan pemahaman siswa serta solusi pemecahan masalah terhadap kendala yang dihadapi. Adapun langkah-langkah keseluruhan kegiatan pengabdian kepada masyarakat dapat dillihat pada tabel berikut:

Tabel 1. Tahapan Kegiatan

\begin{tabular}{clc}
\hline No & \multicolumn{1}{c}{ Kegiatan } & Keterangan \\
\hline 1 & Persiapan & Tim PkM \\
2 & Survey lokasi sekaligus identifikasi & Tim PkM dan Mitra \\
3 & kendala/permasalahan mitra & Tim PkM dan Mitra \\
4 & Pelaksanaan kegiatan dan evaluasi & Tim PkM \\
5 & Publikasi & Tim PkM \\
\hline
\end{tabular}

Pada tahap persiapan dilakukan oleh tim pengabdi dengan membuat proposal kegiatan pengabdian kepada masyarakat. Proposal dibuat sebagai acuan dan gambaran singkat kegiatan pengabdian yang dilakukan. Tahap survey dilakukan untuk melihat kondisi lapangan sekaligus identifikasi kendala yang dihadapi oleh mitra. Tahap selanjutnya pelaksanaan kegiatan pengabdian yang diisi dengan penyampaian materi melalui ceramah dan dilanjutkan dengan diskusi. Hasil diskusi sekaligus sebagai bahan evaluasi untuk melihat hasil tingkat pemahaman siswa dalam literasi digital sehingga siswa mampu mengubah sikap perilaku dalam penggunaan teknologi komunikasi yang bertanggung jawab. Keaktifan siswa dalam berdiskusi dan bertanya serta antusias yang diberikan menunjukkan keberhasilan kegiatan pengabdian yang dilakukan. Tahap berikutnya pembuatan laporan kegiatan pengabdian yang dilakukan oleh tim pengabdi 
sebagai bentuk pertanggung jawaban kegiatan yang dilakukan. Setelah itu tahap mempersiapkan luaran berupa publikasi kegiatan.

\section{HASIL DAN PEMBAHASAN}

Pelaksanaan kegiatan pengabdian kepada masyarakat yang dilakukan di MTs Uswatun Hasanah Mirza Kota Binjai cukup menggembirakan. Hasil pengamatan tim pelaksana pengabdian di lokasi bahwa apresiasi terhadap kegiatan ini tidak hanya diperoleh dari pimpinan sekolah dan guru-guru tetapi juga dari siswa yang mengikuti kegiatan pengabdian ini. Apresiasi dari siswa ditunjukkan dengan antusias kehadiran dan pertanyaan-pertanyaan yang disampaikan pada saat kegiatan berlangsung. Terlihat mereka ingin memahami betul mengenai penggunaan teknologi komunikasi yang sering digunakan secara bertanggung jawab sehingga dapat membentuk karakter yang diharapkan. Pembentukan karakter seperti yang diungkapkan para ahli di atas tidak terlepas dari peran teknologi digital yang berkembang pesat saat ini.

Pada tahap persiapan dilakukan dengan membuat proposal kegiatan pengabdian kepada masyarakat sebagai acuan dan peta konsep dalam pelaksanaan kegiatan. Pada tahap ini dilakukan tanpa ada hambatan yang berarti. Tahap survey dan sekaligus identifikasi permasalahan mitra juga dilakukan tanpa kendala. Tim pengabdian melakukan survey ke MTs Uswatun Hasanah Mirza Kota Binjai dan bertemu langsung dengan kepala sekolah/madrasah untuk meminta izin dan berdiskusi terkait permasalahan yang terjadi secara khusus selama pelaksanaan pembelajaran daring berlangsung. Menurut kepala sekolah/madrasah bahwa hasil pertemuan dengan para orang tua siswa yang dilakukan secara berkala mereka mengeluhkan anak di rumah lebih banyak bermain gadget daripada belajar hingga lupa waktu, lupa belajar dan bahkan lupa terhadap setoran hafalan yang ditugaskan. Kemudian anak juga terlihat berkurang dan menurun minat belajarnya dan bahkan malas-malasan untuk belajar. Lebih miris lagi anak cenderung tidak menghargai dan menghormati orang tua bahkan ada yang melawan kepada orang tuanya. Permasalahan inilah kemudian menjadi bahan tim untuk menentukan tema literasi digital dalam pembentukan karakter siswa dalam kegiatan pengabdian kepada masyarakat. Tahap pelaksanaan dilakukan sesuai dengan rencana kegiatan yang sudah dirumuskan sebelumnya. Pelaksanaan melalui ceramah dengan menyampaikan presentasi materi dan dilanjutkan dengan diskusi. Pada tahap ini mitra berperan memfasilitasi tempat kegiatan dan menghadirkan guru serta siswa/i kelas IX.

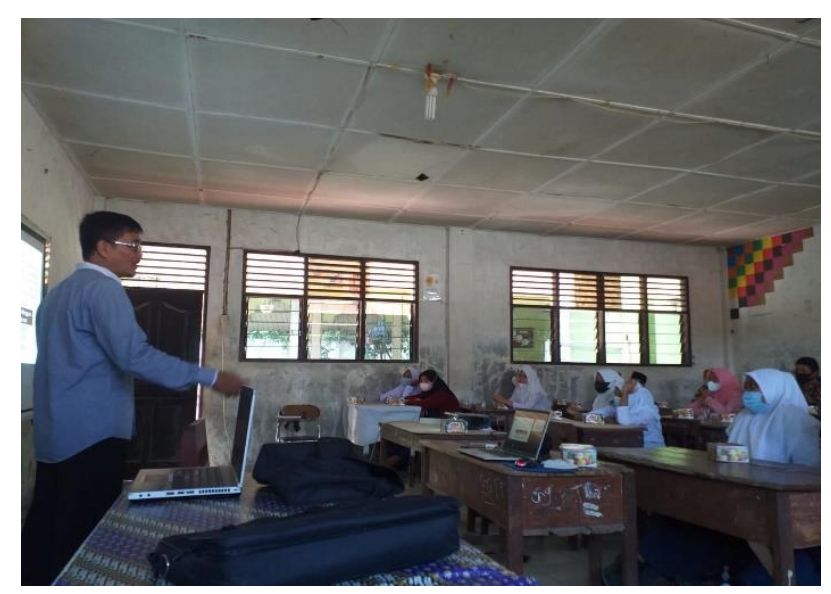

Gambar 1. Penyampaian materi literasi digital dalam pembentukan karakter siswa

Diskusi ditandai dengan antusias siswa/i dalam bertanya dan langsung melihat dan mempraktekkan penggunaan teknologi digital yang berkarakter. Hal ini juga sebagai evaluasi terhadap pemahaman siswa terkait literasi digital dan menggunakannya secara bertanggung jawab dalam membentuk karakter siswa. Kemudian kegiatan dilanjutkan dengan kesediaan siswa/i untuk menjadi duta kampanye dalam gerakan literasi digital. 


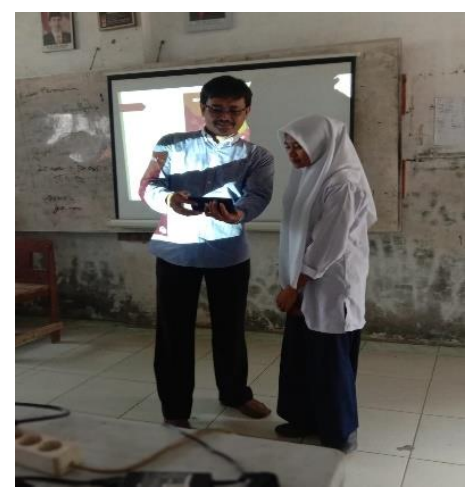

Gambar 2. Diskusi dan menunjukkan salah satu aplikasi digital kepada siswi

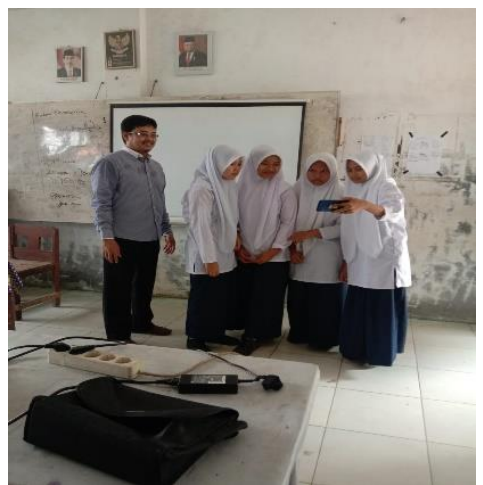

Gambar 7: Diskusi dan menunjukkan aplikasi digital kepada siswi

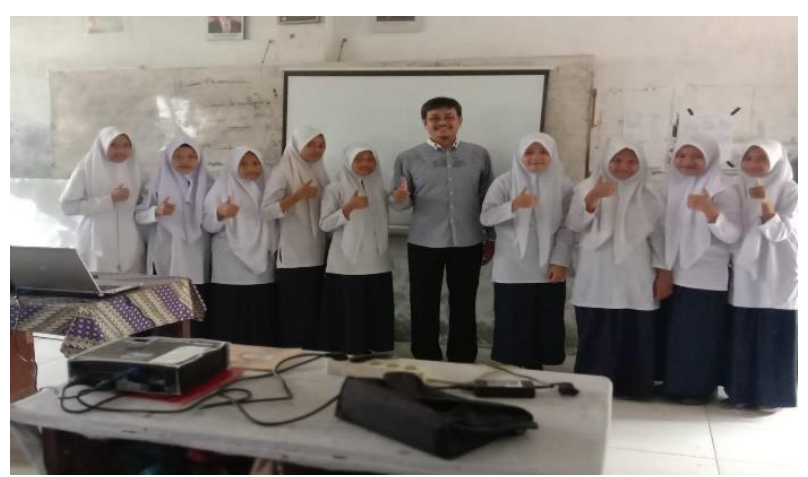

Gambar 8: Beberapa siswi bersedia menjadi duta kampanye gerakan literasi digital

Tahap pembuatan laporan dilaksanakan oleh tim pengabdian untuk melaporkan dan mempertanggungjawabkan kegiatan dan penggunaan dana pengabdian kepada masyarakat. Setelah itu tahapan terakhir yaitu mempublikasi kegiatan dalam bentuk pengiriman naskah artikel pengabdian kepada masyarakat ke jurnal yang terpercaya.

Teknologi digital sebagai sarana mempermudah dalam memenuhi kebutuhan hidup manusia tidak dapat dipungkiri keberadaannya. Situasi pandemi saat ini mengharuskan physical distancing dan pembatasan pergerakan juga mendorong pemanfaatan internet secara intensif untuk berbagai urusan, termasuk pendidikan. Anak-anak masa kini pun, tak pelak lagi, bertumbuh kembang dalam dunia yang sepenuhnya digital. Kendati terdapat peningkatan yang cukup baik dalam relasi antara aktivitas dan kemampuan literasi aktivitas digital kaum muda Indonesia, namun mereka masih rentan terpapar aktivitas-aktivitas mencemaskan seperti cyberbullying, persekusi online, hoaks, ujaran kebencian, konten radikal, pornografi, kekerasan daring, penipuan daring, pencurian data, serangan siber, dan lain-lain (Wijayanto, Fitriyani dan Nurhayati, 2019; Monggilo, Kurnia dan Banyumurti, 2020). Oleh karena itu, sebagai bangsa Indonesia perlu diperhatikan bahwa penggunaan internet harus benar dan sesuai dengan kecakapan yang berlandaskan Pancasila dan Bhinneka Tunggal Ika. Keduanya menjadi landasan 
yang kuat dalam bersosialisasi di masyarakat baik secara tatap muka maupun melalui kegiatan dalam jaringan (daring). Sikap sesuai Pancasila ditunjukkan dalam berbagai kegiatan, salah satunya melalui aplikasi media sosial dengan memahami dan mengedepankan nilai nilai Pancasila dalam berkomunikasi antar sesama manusia, seperti Nilai Sila Ketuhanan Yang Maha Esa (menghomati agama dan keyakinan orang lain, membantu orang lain yang sedang kesusahan, toleransi dsb), atau Nilai Persatuan Indonesia (informasi yang disharing ke media sosial tetap menjaga rasa persatuan dan kesatuan, tidak berisi ujaran kebencian, hoaks, fitnah dsb). Indikator ketercapaian tujuan kegiatan pengabdian adalah $75 \%$ di mana siswa memahami konsep literasi digital dan menggunakannya secara bertanggung jawab dalam pembentukan karakter sehingga mereka diarahkan sebagai duta kampanye gerakan literasi digital yang bertanggung jawab sebagai upaya pembentukan karakter yang berlandaskan Pancasila dan Bhinneka Tunggal Ika.

\section{KESIMPULAN}

Berdasarkan kajian literatur yang diuraikan di atas, maka dapat disimpulkan bahwa keberadaan teknologi digital adalah sebuah keniscayaan yang harus disikapi dengan bijak. Siswa MTs Uswatun Hasanah Mirza Kota Binjai selama pandemi berlangsung melaksanakan kegiatan belajar-mengajar melalui daring. Namun banyak keluhan dari para orang tua selama pembelajaran melalui daring berlangsung seperti penggunaan teknologi komunikasi tanpa batas, menurunnya minat belajar siswa dan perilaku siswa yang kurang menghargai dan menghormati orang lain terlebih orang tua dan keluarganya. Kegiatan pengabdian kepada masyarakat yang dilakukan di sekolah tersebut memberi hasil yang memuaskan di mana siswa mendapat pencerahan dan pemahaman mengenai penggunaan teknologi digital dalam pembentukan karakter yang bertanggung jawab, hal ini ditandai dengan kesediaan mereka sebagai duta kampanye gerakan literasi digital dalam pembentukan karakter yang berlandaskan Pancasila dan Bhinneka Tunggal Ika di sekolahnya. Melalui gerakan literasi digital di sekolah bertujuan untuk meningkatkan motivasi siswa dalam belajar, mengembangkan kreatifitas berpikir siswa serta menumbuhkan integritas siswa dan guru agar tercipta siswa-siswi hebat yang dapat bersaing di era globalisasi saat ini.

\section{DAFTAR PUSTAKA}

Administrator. (2019). Pendidikan Karakter: Pengertian, Fungsi, Tujuan dan Urgensinya. SMK Widya Nusantara. https://smkwidyanusantara.sch.id/read/5/pendidikan-karakterpengertian-fungsi-tujuan-dan-urgensinya.

Ahlah, S., \& Melianah, Melianah. (2020). Membangun Karakter Siswa Melalui Literasi https://jurnal.univpgri-palembang.ac.id.

Monggilo, Z.M.Z., Kurnia, N., \& Banyumurti, I. (2020). Panduan Literasi Media Digital dan Keamanan Siber: Muda, Kreatif, dan Tangguh di Ruang Siber. Jakarta: Badan Siber dan Sandi Negara.

Nasrullah, R., Aditya, W., Satya, T.I., Nento, M.N., Hanifah, N., Miftahussururi, \& Akbari, Q.S. (2017). Literasi Digital. Jakarta: Kementerian Pendidikan dan Kebudayaan.

Nurhajati, L., Wijayanto, X.A., \& Fitriani, L.R. (2019). Panduan Menjadi Jurnalis Warga yang Bijak Beretika. Jakarta : Penerbit LP3M LSPR.

Saptono. (2011). Dimensi-Dimensi Pendidikan Karakter. Jakarta: Esensi.

Savitra, K. (2017). 15 Pengertian Karakter Menurut Para Ahli. https://dosenpsikologi.com/pengertian-karakter-menurut-para-ahli.

Sekretariat TIM GLN Kemdikbud. (2017). Panduan Gerakan Literasi Nasional. Kementerian Pendidikan dan Kebudayaan.

Wikipedia. (2021). Literasi Digital. Ensiklopdedia Bebas. https://id.wikipedia.org/wiki/Literasi digital 


\section{Halaman Ini Dikosongkan}

